\title{
Pancreatic islets of bank vole show signs of dysfunction after prolonged exposure to high glucose concentrations in vitro
}

\author{
Martin Blixt ${ }^{1}$, Bo Niklasson ${ }^{1,2}$ and Stellan Sandler ${ }^{1}$ \\ ${ }^{1}$ Department of Medical Cell Biology, Uppsala University, PO Box 571, SE-751 23 Uppsala, Sweden \\ ${ }^{2}$ Apodemus AB, SE-114 53 Stockholm, Sweden \\ (Correspondence should be addressed to M Blixt; Email: martin.blixt@mcb.uu.se)
}

\begin{abstract}
Bank voles develop glucose intolerance/diabetes mellitus when kept in captivity. We have characterized $\beta$-cell function of glucose intolerant/diabetic animals, and found that this animal model has features of both human type 1 and type 2 diabetes. The aim of this study was to study the functional alterations of islets isolated from glucose tolerant bank voles after a prolonged exposure to various glucose concentrations in vitro. For this purpose, pancreatic islets from normal (glucose tolerant) male and female bank voles were cultured at different glucose concentrations $(5 \cdot 6,11 \cdot 1$ (control), or $28 \mathrm{mM}$ ) whereupon islet functions were examined. Overall, islet insulin output was lowered at $5.6 \mathrm{mM}$ glucose, and similar to control, or enhanced after culture in $28 \mathrm{mM}$ glucose. High glucose culture led to decreased insulin contents, but there was no change in islet DNA content and in morphological
\end{abstract}

assessments of cell death, with the latter findings suggesting that the so-called glucotoxicity had not evolved. A slight gender difference was observed in that islets isolated from females exhibited a glucose-regulated (pro)insulin biosynthesis rate and insulin gene expression. In conclusion, we have found that islets isolated from female and male bank voles are affected by glucose concentrations in vitro in that some signs of dysfunction were observed upon high glucose exposure. A minor gender difference was observed suggesting that the islets of the females may more readily adapt to the elevated glucose concentration than islets of the male bank voles. It could be that these in vitro gender differences observed may represent a mechanism underlying the gender difference in diabetes development observed among bank voles.

Journal of Endocrinology (2010) 206, 47-54

\section{Introduction}

It has been postulated that an increased glucose load in vivo on islet $\beta$-cells may participate in disease progression in type 1 and type 2 diabetes (Weir et al. 1986, 2009, Rossetti et al. 1990, Wilkin 2001, Chang-Chen et al. 2008, Ljungkrantz et al. 2008). In type 2 diabetes, an increased glucose concentration damages the $\beta$-cell mass in the pancreatic islets, for instance by generation of noxious free oxygen radicals which can affect insulin production (Robertson et al. 2003). During the disease progression in type 1 diabetes, the $\beta$-cell mass in the pancreatic islets is reduced by immune cell-mediated mechanisms (Hitchcock et al. 1988, Bach 1995, Yoon \& Jun 2005, Knip \& Siljander 2008). An increased functional demand on isolated islets in vitro has shown that hyperglycemic-like conditions can alter islet function and be detrimental for the $\beta$-cell, but depending on the species of origin, this effect varies (Eizirik et al. 1988, 1991, 1992a, Sandler et al. 1989, Gross et al. 1996).

Bank voles develop glucose intolerance/diabetes mellitus both in the wild state and when kept in captivity, and male bank voles seem to a larger extent be affected compared with the females (Schoenecker et al. 2000, Niklasson et al. 2003a,b,
Blixt et al. 2007). We have recently characterized $\beta$-cell function of pancreatic islets isolated from normal and glucose intolerant/diabetic bank voles, and found that this animal model has features of both human type 1 and type 2 diabetes (Blixt et al. 2007). Moreover, a novel picornavirus (Ljungan virus) was isolated from bank voles (Niklasson et al. 1999) and was later found in the pancreas of wild bank voles (Niklasson et al. 2003a). However, its possible role in the development of diabetes in the bank voles remains to be proven. It has been shown in CD-1 mice that when the mother is inoculated with the Ljungan virus during gestation the offspring develops diabetes (Niklasson et al. 2006).

The aim of this study was to study the functional alterations of islets isolated from glucose tolerant bank voles after exposure to a prolonged exposure to various glucose concentrations in vitro. Glucose is the main carbohydrate regulator of $\beta$-cell activity, and therefore it is of particular interest to investigate the effects of glucose in a novel animal model of diabetes. Herein we report that islets of bank vole display signs of dysfunction after high glucose culture, and that there are slight gender differences suggesting that the islets from male bank voles may have a reduced ability to meet an increased functional demand. 


\section{Materials and Methods}

\section{Animals}

Bank voles (Myodes glareolus) were housed at Astrid Fagreus Laboratory, Karolinska Institute, Stockholm. Animals had free access to water and standard laboratory chew (LABFOR R3, Lactamin, Kimstad, Sweden) with an energy content of $3 \cdot 01 \mathrm{kcal} / \mathrm{g}$, and were occasionally given pieces of vegetables. The nesting material in the cages was exchanged 2-3 times/week by experienced animal technicians. The experimental procedures were approved by the animals' ethical committee in Stockholm (N248/03, N276/06) and in accordance with international guidelines (NIH publications no. 85-23, revised 1985).

The mean age of the bank voles used was $14 \cdot 5 \pm 1 \cdot 5$ weeks ( $n=46$; range 4-40 weeks) for females, and $17 \cdot 4 \pm 1 \cdot 1$ weeks ( $n=59$; range 4-42 weeks) for males. All animals were tested with an i.p. glucose tolerance test, where 2 g glucose $/ \mathrm{kg}$ body weight was injected. Blood samples were taken from the retro-orbital sinus immediately prior to injection $(0 \mathrm{~min})$, and at 60 and $120 \mathrm{~min}$ post injection. The samples were analyzed with an automated glucose meter (Accu-Chek Aviva; Roche Diagnostics). The animals were anaesthetized with Isoflurane (Abbott Inc.) prior to blood sampling and prior to killing by cervical dislocation. Bank voles with a blood glucose concentration below $11.1 \mathrm{mM}$ at $120 \mathrm{~min}$ post injection were classified as normoglycemic.

The pancreas of normoglycemic bank voles was resected and placed in Hanks' balanced salt solution (SBL Vaccine, Stockholm, Sweden) supplemented with $50 \mathrm{U} / \mathrm{ml}$ benzylpenicillin and $0.05 \mathrm{mg} / \mathrm{ml}$ streptomycin (Sigma-Aldrich).

\section{Islet isolation and pre-culture}

Pancreatic islets were isolated by collagenase digestion as described elsewhere (Blixt et al. 2007). Islets from individual bank voles were maintained free-floating in separate culture dishes in culture medium RPMI 1640 with $11 \cdot 1 \mathrm{mM}$ glucose supplemented with $10 \%$ v/v FCS, $2 \mathrm{mM}$ glutamine and $50 \mathrm{U} / \mathrm{ml}$ benzylpenicillin, and $0.05 \mathrm{mg} / \mathrm{ml}$ streptomycin at $37^{\circ} \mathrm{C}$, in humidified air $+5 \% \mathrm{CO}_{2}$ (AGA, Stockholm, Sweden) for 5 days. Culture media were exchanged every second day.

\section{Experimental culturing conditions}

Islets from two bank voles of the same gender and similar body weight were pooled and distributed into three new culture dishes with 50 islets of equal size in each, and were further cultured for 5 days in culture media supplemented with glucose to a final concentration of $5 \cdot 6,11 \cdot 1$, or $28 \mathrm{mM}$ before examination. The culture media were exchanged on days 1 and 3 . In separate experiments, islets were cultured in medium containing $11.1 \mathrm{mM}$ D-glucose $+16.9 \mathrm{mM}$ L-glucose to explore possible osmotic effects of a high glucose concentration.

\section{Medium insulin and proinsulin accumulation, islet insulin release, and insulin content}

Media from the last $48 \mathrm{~h}$ of culture were collected for determination of medium insulin and proinsulin accumulation. The insulin release was tested in triplicate groups of ten islets incubated at $1.7 \mathrm{mM}$ glucose in Krebs-Ringer bicarbonate buffer (KRBH; Krebs \& Henseleit 1932) supplemented with $2 \mathrm{mg} / \mathrm{ml}$ BSA at $37^{\circ} \mathrm{C}\left(\mathrm{O}_{2} / \mathrm{CO}_{2}\right.$; $95 / 5 \%)$ for $1 \mathrm{~h}$. Subsequently, the buffer was replaced with KRBH supplemented with $16.7 \mathrm{mM}$ and $2 \mathrm{mg} / \mathrm{ml}$ BSA followed by incubation for another $1 \mathrm{~h}$. Islet insulin content was measured on islets pooled from the incubation above after disruption in water and extraction overnight at $4{ }^{\circ} \mathrm{C}$ using $70 \% \mathrm{v} / \mathrm{v}$ ethanol supplemented with $0.13 \mathrm{mM} \mathrm{HCl}$. The insulin concentrations in the culture media, the incubation buffers, and the insulin extractions were measured with either a rat insulin high range ELISA kit or a rat insulin ELISA kit (Mercodia, Uppsala, Sweden). The proinsulin concentration in the culture media was measured with a rat Proinsulin ELISA kit (Mercodia). No commercial antibodies specific for bank vole insulin or proinsulin are available. This means that absolute values measured herein may be different to actual levels of bank vole insulin or proinsulin.

\section{Islet total protein and (pro)insulin biosynthesis and glucose oxidation rates}

The islet total protein and (pro)insulin biosynthesis and glucose oxidation rate were measured on groups of ten islets in duplicates incubated in $\mathrm{KRBH}$ containing $16.7 \mathrm{mM}$ glucose and ${ }^{3} \mathrm{H}$-labeled leucine (protein and (pro)insulin biosynthesis), or D-[U- $\left.{ }^{14} \mathrm{C}\right]$ glucose (glucose oxidation rate), and further analysis was performed as described previously (Blixt et al. 2007).

\section{$R N A$ isolation, $c D N A$ synthesis, and real-time PCR}

RNA was isolated from groups of 50 islets with RNeasy Micro kit (Qiagen) complemented with DNase (Qiagen) and eluted in water. The RNA amount and purity were tested using the Nanodrop ND-1000 system (NanoDrop Technologies, Wilmington, DE, USA). Synthesis of cDNA was performed with Reverse Transcription System (Promega) using 1:2 volume of total RNA and Oligo(dT)15 primer (Promega). The reaction mixtures were incubated at $42^{\circ} \mathrm{C}$ in $60 \mathrm{~min}$ followed by $99^{\circ} \mathrm{C}$ in $5 \mathrm{~min}$.

The LightCycler Instrument (Roche) combined with sequence-independent detection with SYBR Green I was used to amplify and analyze generated cDNA. The sequence of the primers used were: insulin (mouse) forward $5^{\prime}$-CCAT-

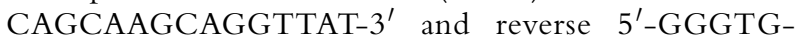
TGTAGAAGAAGCCA- $3^{\prime}$, and $\beta$-actin (mouse) forward 
$5^{\prime}$-CCACCGATCCACACAGAGTACTTG-3' and reverse $5^{\prime}$-GCTCTGGCTCCTAGCACC-3' (TIB MOLBIOL Syntheselabor GmbH, Berlin, Germany) PCR amplification of $0 \cdot 1 \mu \mathrm{g}$ cDNA sample was performed with $0 \cdot 2 \mu \mathrm{M}$ insulin primer and $0.5 \mu \mathrm{M} \beta$-actin primer in SYBR Green JumpStart ready mixture (Roche) and $3.5 \mathrm{mmol} / 1 \mathrm{MgCl}_{2}$. After an initial $95^{\circ} \mathrm{C}$ in $30 \mathrm{~s}$, the following temperatures were cycled 40 times; $94^{\circ} \mathrm{C}$ in $5 \mathrm{~s}, 47^{\circ} \mathrm{C}$ in $10 \mathrm{~s}$ and $72{ }^{\circ} \mathrm{C}$ in $15 \mathrm{~s}$. Cycle threshold $\left(C_{\mathrm{t}}\right)$ values were obtained for individual samples with the second derivative maximum method (Gibson et al. 1996, Heid et al. 1996). The relative mRNA expression was calculated from the formula $2^{-\left(\Delta C_{\mathrm{t}}\right)}$.

\section{DNA quantification}

DNA content was measured with fluorometric assay using PicoGreen (Molecular Probes, Eugene, CA, USA) labeling system according to the instructions of the manufacturer. The DNA content was measured in water homogenates in conjunction to determinations of the islet insulin content, and total protein and (pro)insulin biosynthesis rates.

\section{Islet viability}

Viability of bank vole islet cells was determined using Hoechst 33342 and propidium iodide. In each test, at least ten islets were incubated with $5 \mu \mathrm{g} / \mathrm{ml}$ bisbenzimide and $20 \mu \mathrm{g} / \mathrm{ml}$ propidium iodide for $20 \mathrm{~min}$. After washing in PBS, fluorescence was observed at 461 and $615 \mathrm{~nm}$ respectively after u.v. excitation. The islets were photographed in a fluorescence microscope, and the nuclear morphology was later assessed and cell numbers were counted by the observer being unaware of the origin of the specimens.

\section{Statistical analysis}

A mean was calculated from each duplicate or triplicate groups of islets, and then considered as one separate observation. Values are expressed as means \pm s.E.M., and groups of data were compared using Student's paired $t$-tests. Observed differences were considered statistically significant when $P \leq 0 \cdot 05$. Statistical analysis was performed using SigmaStat (SPSS Inc., Chicago, IL, USA).

\section{Results}

The non-fasting blood glucose concentration of the glucose tolerant/normal bank voles used was $6 \cdot 5 \pm 0 \cdot 3 \mathrm{mM}(n=59)$ for males, and $7 \cdot 2 \pm 0 \cdot 6 \mathrm{mM}(n=46)$ for females. All islets were precultured for 5 days in RPMI $1640(11.1 \mathrm{mM}$ glucose), and then the islets were subsequently cultured in media containing $5 \cdot 6,11 \cdot 1$, or $28 \mathrm{mM}$ glucose for another 5 days. We have chosen to consider the islets cultured in medium with $11.1 \mathrm{mM}$ glucose as the control group, since this is the regular glucose concentration of the RPMI 1640 medium. Moreover, previous studies from our laboratory have suggested that $11.1 \mathrm{mM}$ glucose may be an optimal glucose concentration for maintenance of insulin production of isolated rodent islets in RPMI 1640 medium (Andersson 1978, Svensson et al. 1993).

\section{Medium insulin and proinsulin accumulation during culture}

Insulin and proinsulin accumulation in the culture medium was measured in samples obtained from the last $48 \mathrm{~h}$ of culture. In comparison with the control islets, the insulin accumulation was reduced in islets isolated from male and female bank voles cultured in $5.6 \mathrm{mM}$ glucose (Table 1). On the other hand, at $28 \mathrm{mM}$ glucose there was an increase in insulin accumulation from islets of both genders compared with the control group.

Proinsulin levels in the media were elevated after culture of islets from males and females in $28 \mathrm{mM}$ glucose, whereas media collected from islets cultured in $5.6 \mathrm{mM}$ glucose displayed a decline. The proinsulin fraction, expressed as percentage of total medium insulin accumulation, was

Table 1 Medium insulin and proinsulin accumulation after culture of bank vole islets at 5•6, $11 \cdot 1$ and $28 \mathrm{mM}$ glucose. The islets were cultured for 5 days and medium was exchanged after 1 and 3 days. Insulin and proinsulin medium accumulation was measured during the last $48 \mathrm{~h}$ of culture. Values are means \pm s.E.M. for $(n)$ observations

\begin{tabular}{|c|c|c|c|c|c|c|}
\hline & \multicolumn{3}{|l|}{ Male islets } & \multicolumn{3}{|l|}{ Female islets } \\
\hline & $5.6 \mathrm{mM}$ glucose & $11 \cdot 1 \mathrm{mM}$ glucose & $28 \mathrm{mM}$ glucose & $5.6 \mathrm{mM}$ glucose & $11 \cdot 1 \mathrm{mM}$ glucose & $28 \mathrm{mM}$ glucose \\
\hline \multicolumn{7}{|l|}{ Culture } \\
\hline $\begin{array}{l}\text { Medium proinsulin } \\
\text { accumulation } \\
(\text { ng/10 islets } \times 24 \mathrm{~h})\end{array}$ & $0 \cdot 5 \pm 0 \cdot 2(11)^{+}$ & $4 \cdot 4 \pm 0 \cdot 5(11)$ & $14 \cdot 5 \pm 2 \cdot 2(11)^{\dagger}$ & $0 \cdot 2 \pm 0 \cdot 03(7)^{\dagger}$ & $4 \cdot 0 \pm 0 \cdot 6(7)$ & $11 \cdot 5 \pm 1 \cdot 9(7)^{* *}$ \\
\hline $\begin{array}{l}\text { Proinsulin fraction } \\
\text { (\% of medium } \\
\text { insulin) }\end{array}$ & $0 \cdot 3 \pm 0 \cdot 1(11)$ & $0 \cdot 4 \pm 0 \cdot 04(11)$ & $1 \cdot 0 \pm 0 \cdot 1(11)^{+}$ & $0 \cdot 1 \pm 0 \cdot 02(7)^{* *}$ & $0 \cdot 4 \pm 0 \cdot 1(7)$ & $0 \cdot 9 \pm 0 \cdot 1(7)^{\dagger}$ \\
\hline
\end{tabular}

Data were compared using Students ${ }^{\prime}$ paired $t$-test where ${ }^{*}$ denote $P \leq 0 \cdot 05,{ }^{* *}$ denote $P \leq 0 \cdot 01$ and ${ }^{+}$denote $P \leq 0 \cdot 001$ versus islets cultured at $11 \cdot 1$ mM glucose of the same gender. 


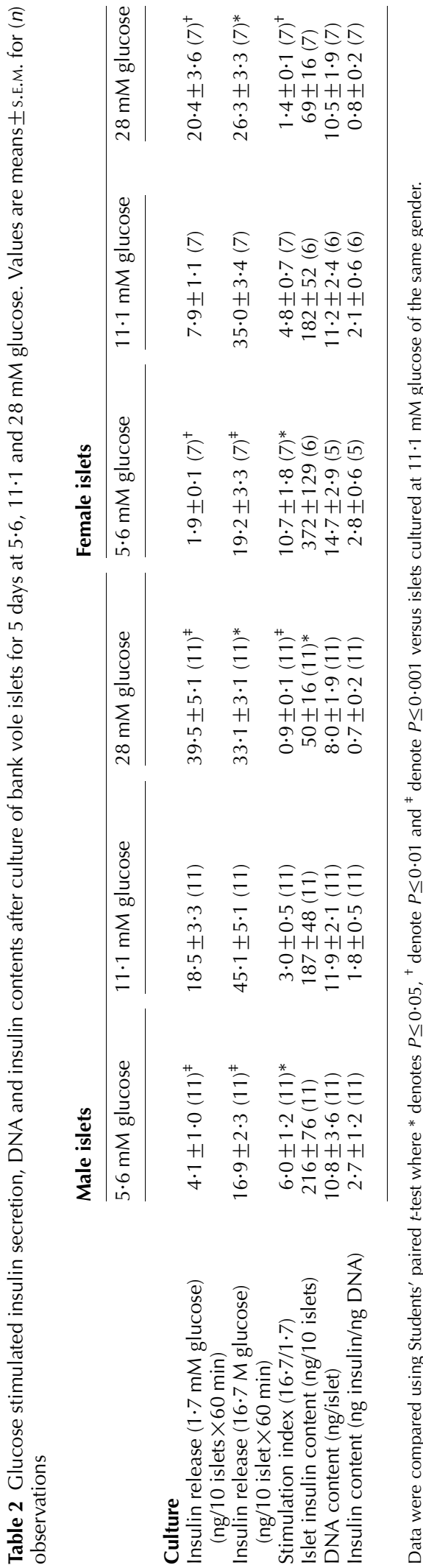

Journal of Endocrinology (2010) 206, 47-54 increased in media from both male and female islets cultured in $28 \mathrm{mM}$ glucose, and for the females a decrease was observed at $5.6 \mathrm{mM}$ glucose.

\section{Glucose-stimulated insulin secretion}

Islets isolated from both male and female bank voles maintained in $5.6 \mathrm{mM}$ glucose showed a reduced basal insulin secretion at low glucose conditions ( $1.7 \mathrm{mM}$ glucose), but when islets were cultured in $28 \mathrm{mM}$ glucose, the islet basal insulin secretion was markedly elevated compared with control islets (Table 2). Furthermore, the glucose-stimulated insulin release $(16.7 \mathrm{mM}$ glucose) was reduced in islets of males and females after culture in $5.6 \mathrm{mM}$ and after culture in $28 \mathrm{mM}$ glucose compared with islets cultured in $11.1 \mathrm{mM}$ glucose. The stimulation index, the fraction between the insulin release upon a glucose challenge and the basal insulin secretion, was increased in islets isolated from males and females cultured in $5.6 \mathrm{mM}$ glucose compared with control islets, whereas it was lowered for the islets cultured in $28 \mathrm{mM}$ glucose.

\section{Insulin and DNA content}

The islet insulin content was measured after the insulin release assay (Table 2). Islets from female and male bank voles were not affected when cultured in $5.6 \mathrm{mM}$ glucose compared with the corresponding controls. However, the insulin content of islets from both genders was markedly reduced after culture in the high $28 \mathrm{mM}$ glucose for male islets, but for female islets this decline did not attain statistical significance $(P=0.064)$ compared with islets cultured in $11.1 \mathrm{mM}$ glucose. The islet DNA content was not affected by the different glucose concentrations in any of the groups of islets. When the islet insulin content was normalized according to the DNA content, the islet insulin content was still reduced after culture in $28 \mathrm{mM}$, but the differences did not attain statistical significance (males $P=0.052$ and females $P=0 \cdot 067)$.

\section{Islet (pro)insulin and total protein biosynthesis rates and insulin $m R N A$ levels}

The islet (pro)insulin and total protein biosynthesis rates were measured during a 2-h incubation at $16.7 \mathrm{mM}$ glucose, and normalized according to the DNA content in each observation. Islets isolated from male bank voles displayed no differences in (pro)insulin or total protein biosynthesis rate between any of the groups (Table 3). On the other hand, islets isolated from female bank voles and maintained in $5.6 \mathrm{mM}$ glucose had a reduced islet (pro)insulin biosynthesis rate compared with islets cultured in $11.1 \mathrm{mM}$ glucose. Concerning total protein biosynthesis rates, islets from females cultured in $5.6 \mathrm{mM}$ glucose exhibited a reduction, but at $28 \mathrm{mM}$ glucose, they had an elevated total protein biosynthesis rate compared with the control islets. 
Table 3 (Pro)insulin biosynthesis rates and insulin gene expression after culture of bank vole islets for 5 days in culture at $5 \cdot 6,11 \cdot 1$ and $28 \mathrm{mM}$ glucose. Values are means \pm s.E.M. for $(n)$ observations

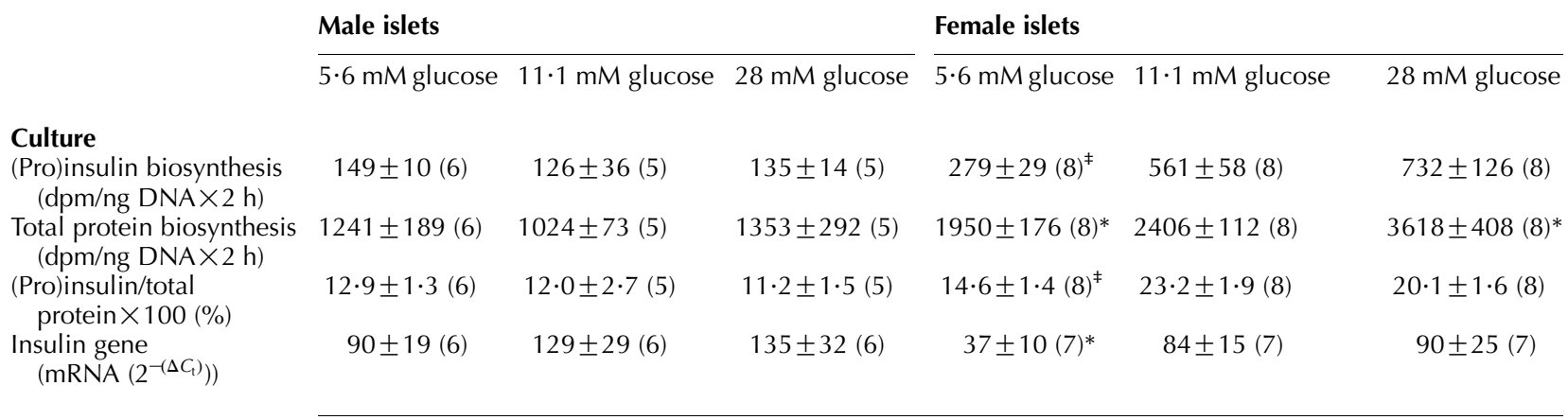

Data are compared using Student's paired $t$-test where * denotes $P \leq 0 \cdot 05$, and $^{\ddagger}$ denote $P \leq 0 \cdot 001$ versus islets cultured at $11 \cdot 1 \mathrm{mM}$ glucose of the same gender.

The (pro)insulin biosynthesis, expressed as percentage of total protein biosynthesis rate, was reduced in islets isolated from female bank voles cultured in $5.6 \mathrm{mM}$ glucose compared with control islets, while no difference in this measurement was found in islets isolated from male animals. The insulin gene expression was not affected by the different glucose concentrations concerning male islets, but for female islets a reduction was observed for islets maintained in $5 \cdot 6 \mathrm{mM}$ glucose.

\section{Islet glucose oxidation rate}

Islet glucose oxidation rates were measured during 90-min incubation at $16.7 \mathrm{mM}$ glucose at the end of the culture period. It was found that the glucose oxidation rates were

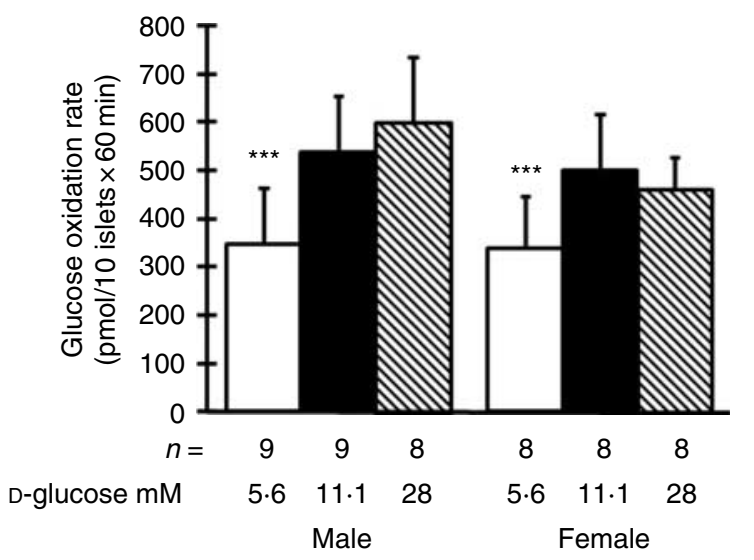

Figure 1 Glucose oxidation rates of male and female bank vole islets cultured in $16.7 \mathrm{mM}$ glucose after culture in $11.1 \mathrm{mM}$ glucose for 5 days and subsequently cultured in $5 \cdot 6,11 \cdot 1$, or $28 \mathrm{mM}$ glucose for 5 days. Values are means \pm S.E.M. for $(n)$ observations as shown below the bars. Data were compared using Student's paired $t$-test where ${ }^{* * *} P \geq 0.001$ versus those obtained from islets cultured in $11 \cdot 1 \mathrm{mM}$ glucose of the same gender. reduced after culture in $5.6 \mathrm{mM}$ glucose for both genders; however, no change could be observed in islets cultured in $28 \mathrm{mM}$ glucose compared with controls (Fig. 1).

\section{Test of osmotic effects}

In a separate set of experiments $(n=4)$, possible osmotic effects of the increased glucose concentration in the culture medium $(28 \mathrm{mM})$ were tested on islets obtained from both females and males. Isolated islets were cultured in media containing $11.1 \mathrm{mM}$ D-glucose or $11.1 \mathrm{mM}$ D-glucose $+16.9 \mathrm{mM}$ L-glucose. The results did not reveal any differences between the groups when tested for the insulin release $(\mathrm{ng} / 10$ islets $\times 60 \mathrm{~min})$ at $1.7 \mathrm{mM}$ glucose $(11 \cdot 1 \mathrm{mM}$ D-glucose, $28 \cdot 8 \pm 3 \cdot 9$; and $11 \cdot 1 \mathrm{mM}$ D-glucose $+16 \cdot 9 \mathrm{mM}$ L-glucose, $26 \cdot 0 \pm 2 \cdot 2)$ at $16 \cdot 7 \mathrm{mM}$ glucose $(11 \cdot 1$ $\mathrm{mM}$ D-glucose, $53 \cdot 6 \pm 9 \cdot 0$; and $11 \cdot 1 \mathrm{mM}$ D-glucose $+16 \cdot 9 \mathrm{mM}$ L-glucose, $52 \cdot 3 \pm 5 \cdot 3)$, the insulin content (ng/10 islets) (11.1 mM D-glucose, $251 \pm 33$; and $11 \cdot 1 \mathrm{mM}$ D-glucose $+16.9 \mathrm{mM}$ L-glucose, $235 \pm 26$ ), or the medium insulin accumulation ( $\mathrm{ng} / 10$ islets $\times 24 \mathrm{~h}) \quad(11.1 \mathrm{mM}$ D-glucose: $975 \pm 82$; and $11.1 \mathrm{mM}$ D-glucose $+16.9 \mathrm{mM}$ L-glucose, $984 \pm 20$ ) or the medium proinsulin accumulation $(\mathrm{ng} / 10$ islets $\times 24 \mathrm{~h}) \quad(11 \cdot 1 \mathrm{mM}$ D-glucose, $2 \cdot 6 \pm 0 \cdot 4$; and $11 \cdot 1 \mathrm{mM}$ D-glucose $+16 \cdot 9 \mathrm{mM}$ L-glucose, $2 \cdot 4 \pm 0 \cdot 5)$.

\section{Islet viability}

In some experiments, islets were collected for assessment of islet cell viability following staining with Hoechst 33342 and propidium iodide. For female islets, $(n=6)$ the percentage of non-viable islet cells were $4 \cdot 7 \pm 1 \cdot 0,6 \cdot 3 \pm 1 \cdot 2$, and $8 \cdot 0$ $\pm 3 \cdot 1 \%$ at $5.6 \mathrm{mM}$ glucose, $11.1 \mathrm{mM}$ glucose, and $28 \mathrm{mM}$ glucose respectively. For male islets $(n=8)$, the percentage of non-viable islet cells were $6 \cdot 3 \pm 1 \cdot 0,5 \cdot 3 \pm 1 \cdot 1$, and $3 \cdot 6$ $\pm 0.4 \%$ at $5.6 \mathrm{mM}$ glucose, $11.1 \mathrm{mM}$ glucose, and $28 \mathrm{mM}$ 
glucose respectively. No statistical difference was observed in the extent of islet cell death when female or male islets were compared with those cultured in $11.1 \mathrm{mM}$ glucose, using Student's paired $t$-test.

\section{Discussion}

In the present study, we have shown that the function of bank vole islets was markedly affected by long-term exposure to a high glucose concentration in vitro. The functional changes observed share features of both rodent and human islets maintained at similar culture conditions (Eizirik et al. 1988, 1992a). We maintained islets isolated from male and female bank voles, classified as glucose tolerant, for a long-term culture period in vitro. Different glucose concentrations were used in order to assess if glucose affects $\beta$-cell function. In comparison to the control group $(11 \cdot 1 \mathrm{mM}$ glucose), glucose-induced changes were observed in islets of both male and female origin, and we could also observe some differences in islet response between genders.

At the lower glucose concentration $(5.6 \mathrm{mM})$, islets isolated from males and females displayed a down-regulation of both basal and glucose-stimulated insulin release, whereas at high glucose $(28 \mathrm{mM})$, a markedly elevated basal insulin secretion was observed while the glucose-stimulated insulin release was moderately reduced compared with controls. The stimulation index value revealed that the relation between basal and glucose-stimulated insulin release was changed depending on the different glucose concentrations. Thus, the islets maintained in $28 \mathrm{mM}$ glucose seem to have an impaired ability to respond to the high glucose stimulation.

When comparing these findings with previous studies using the RPMI 1640 medium for culture of islets from other species, the insulin release behavior of bank vole islets much resemble normal mouse pancreatic islets of various strains (Eizirik et al. 1988, Svensson et al. 1993). Another interesting rodent in this context is the sand rat (Psammomys obesus), which can develop a type 2 diabetes-like condition in the laboratory when given certain diets (Gadot et al. 1994, 1995). Moreover, in a study where islet cells from normal $P$. obesus were explanted in vitro and cultured as monolayer, it was found that an elevated glucose concentration $(33.3 \mathrm{mM})$ for 10 days caused a pronounced reduction in glucose-induced insulin secretion (Gross et al. 1996). Culture of normal rat islets at high glucose, depending on the selection of culture media, may either cause a decrease in glucose-stimulated insulin secretion the so-called desensitization (Bolaffi et al. 1988) or have no obvious harmful effect (Sandler et al. 1989). In comparison to human islets, the bank vole islets display a similar response in stimulation index and in insulin content with increasing glucose concentration in the culture medium (Eizirik et al. 1992b). Interestingly, we recently found that bank vole islets responded to proinflammatory cytokines in vitro according to a pattern more resembling human islets than that seen in rodent islets (Blixt et al. 2009).
The reduced insulin content in bank vole islets cultured in $28 \mathrm{mM}$ glucose suggests that the islets were not able to comply with the increased functional demand but rendered them to be depleted of insulin. Furthermore, the increased proinsulin amount in the culture medium supplemented with $28 \mathrm{mM}$ glucose may suggest that the islet insulin production capacity was exceeded. This would be in line with observations in P. obesus (Gadot et al. 1995) and in a model of glucose infusion in rats (Alarcon et al. 1995). We also observed that in $11.1 \mathrm{mM}$ glucose the insulin accumulated in the medium was similar to that in $28 \mathrm{mM}$ glucose, and this may suggest that the islets maintained at these culture conditions were facing a too great functional demand on the $\beta$-cells. These findings suggest that the optimal culture condition for bank vole islets is not the standard $11.1 \mathrm{mM}$ glucose, but is closer to $5.6 \mathrm{mM}$ glucose level. This is similar to that of human islets for which the optimal culture condition using RPMI 1640 medium is lower than $11.1 \mathrm{mM}$ glucose (Eizirik et al. 1992b). Based on these findings, we hypothesize that the bank vole islet resembles the human islet more than previously characterized rodent islets.

The islet total protein and (pro)insulin biosynthesis rates showed glucose-induced changes when islets of females were studied, whereas islets from males did not exhibit any glucosedependent alterations in these functions. We interpret this possible gender difference that the female islets are more prone, than male islets, to adapt their (pro)insulin biosynthesis rates and may also be total protein biosynthesis rates to the ambient glucose concentration. Besides for the translational level, this adaption might also be regulated on the transcriptional level since the insulin mRNA expression also displayed glucose dependence in female islets. The islet glucose oxidation rates were not currently affected after culture in high glucose which suggests that an altered glucose metabolism did not mediate glucose-induced impairments in islet function. Furthermore, osmotic effects due to high glucose concentrations are unlikely to have influenced the islet functions investigated.

The Ljungan virus is difficult to isolate in tissue culture. Virus isolation is therefore not used as a diagnostic method. The humoral response is weak. Persistently infected individuals show no or a very weak antibody response, while individuals that clear the infection have detectable antibodies. Serology can therefore not be used to diagnose past or present infection in an individual. Ljungan virus infection often results in a chronic persistent or long-lasting infection. RT-PCR can be used to detect viral RNA in persistently infected animals (Donoso Mantke et al. 2007). PCR positive animals are often found several months after the acute infection. However, the RNA copy number at this time is often low. We have also found several examples where animals have been PCR negative and are still proven infectious. This means that the diagnostic arsenal presently available only allow us to state that our bank vole colony is Ljungan virus infected. We cannot determine with accuracy if an individual with disease is Ljungan virus infected or not, and we cannot determine what proportion of the animals in the colony carry the virus. 
Thus, to what extent each individual animal used herein is infected cannot be determined. If so, how this might have influenced our present findings and if a gender difference in viral susceptiblity has contributed to our current findings is unclear.

Previously we have shown that bank voles developing glucose intolerance/diabetes display features that are to some extent different between genders (Blixt et al. 2007). Herein we have found that islet isolated from female and male bank voles are affected by glucose concentration in vitro in that some signs of dysfunction were observed upon high glucose exposure, although this did not cause direct toxicity and cell death. A minor gender difference was observed suggesting that the islets of the females may more readily adapt to the elevated glucose concentration than islets of the male bank voles. It could be that these in vitro gender differences observed may represent a mechanism underlying the difference in diabetes development observed among bank voles (Blixt et al. 2007).

\section{Declaration of interest}

$\mathrm{BN}$ is $\mathrm{CEO}$ and an owner of Apodemus $\mathrm{AB}$, which holds several patents relating to the Ljungan virus. $\mathrm{MB}$ and SS declare that there is no conflict of interest that would prejudice the impartiality of this scientific work.

\section{Funding}

This study was supported by grants from the Swedish Research Council, the Novo Nordic Fund, the Swedish Diabetes Association, and the Family Ernfors Fund.

\section{Acknowledgements}

We are highly indebted to Ing-Britt Hallgren for excellent technical assistance.

\section{References}

Alarcon C, Leahy JL, Schuppin GT \& Rhodes CJ 1995 Increased secretory demand rather than a defect in the proinsulin conversion mechanism causes hyperproinsulinemia in a glucose-infusion rat model of non-insulindependent diabetes mellitus. Journal of Clinical Investigation 95 1032-1039.

Andersson A 1978 Isolated mouse pancreatic islets in culture: effects of serum and different culture media on the insulin production of the islets. Diabetologia 14 397-404.

Bach JF 1995 Insulin-dependent diabetes mellitus as a beta-cell targeted disease of immunoregulation. Journal of Autoimmunity 8 439-463.

Blixt M, Niklasson B \& Sandler S 2007 Characterization of beta-cell function of pancreatic islets isolated from bank voles developing glucose intolerance/diabetes: an animal model showing features of both type 1 and type 2 diabetes mellitus, and a possible role of the Ljungan virus. General and Comparative Endocrinology 154 41-47.

Blixt M, Niklasson B \& Sandler S 2009 Suppression of bank vole pancreatic islet function by proinflammatory cytokines. Molecular and Cellular Endocrinology 305 1-5.

Bolaffi JL, Bruno L, Heldt A \& Grodsky GM 1988 Characteristics of desensitization of insulin secretion in fully in vitro systems. Endocrinology 122 1801-1809.

Chang-Chen KJ, Mullur R \& Bernal-Mizrachi E 2008 Beta-cell failure as a complication of diabetes. Reviews in Endocrine and Metabolic Disorders 9 329-343.
Donoso Mantke O, Kallies R, Niklasson B, Nitsche A \& Niedrig M 2007 A new quantitative real-time reverse transcriptase PCR assay and melting curve analysis for detection and genotyping of Ljungan virus strains. Journal of Virological Methods 141 71-77.

Eizirik DL, Strandell E \& Sandler S 1988 Culture of mouse pancreatic islets in different glucose concentrations modifies B cell sensitivity to streptozotocin. Diabetologia 31 168-174.

Eizirik DL, Strandell E \& Sandler S 1991 Prolonged exposure of pancreatic islets isolated from "pre-diabetic" non-obese diabetic mice to a high glucose concentration does not impair beta-cell function. Diabetologia 34 6-11.

Eizirik DL, Korbutt GS \& Hellerstrom C 1992a Prolonged exposure of human pancreatic islets to high glucose concentrations in vitro impairs the beta-cell function. Journal of Clinical Investigation 90 1263-1268.

Eizirik DL, Tracey DE, Bendtzen K \& Sandler S $1992 b$ Role of receptor binding and gene transcription for both the stimulatory and inhibitory effects of interleukin-1 in pancreatic beta-cells. Autoimmunity 12 127-133.

Gadot M, Leibowitz G, Shafrir E, Cerasi E, Gross DJ \& Kaiser N 1994 Hyperproinsulinemia and insulin deficiency in the diabetic Psammomys obesus. Endocrinology 135 610-616.

Gadot M, Ariav Y, Cerasi E, Kaiser N \& Gross DJ 1995 Hyperproinsulinemia in the diabetic Psammomys obesus is a result of increased secretory demand on the beta-cell. Endocrinology 136 4218-4223.

Gibson UE, Heid CA \& Williams PM 1996 A novel method for real time quantitative RT-PCR. Genome Research 6 995-1001.

Gross DJ, Leibowitz G, Cerasi E \& Kaiser N 1996 Increased susceptibility of islets from diabetes-prone Psammomys obesus to the deleterious effects of chronic glucose exposure. Endocrinology 137 5610-5615.

Heid CA, Stevens J, Livak KJ \& Williams PM 1996 Real time quantitative PCR. Genome Research 6 986-994.

Hitchcock CL, Riley WJ \& Maclaren NK 1988 Autoimmunity in insulindependent diabetes mellitus: its detection and prevention. Concepts in Immunopathology 5 144-167.

Knip M \& Siljander H 2008 Autoimmune mechanisms in type 1 diabetes. Autoimmunity Reviews 7 550-557.

Krebs HA \& Henseleit K 1932 Untersuchungen ber die Harnstoffbildung im Tierk”rper. Hoppe-Seyler's Zeitschrift für Physiologische Chemie 210 33-66.

Ljungkrantz M, Ludvigsson J \& Samuelsson U 2008 Type 1 diabetes: increased height and weight gains in early childhood. Pediatric Diabetes 9 50-56.

Niklasson B, Kinnunen L, Hornfeldt B, Horling J, Benemar C, Hedlund KO, Matskova L, Hyypia T \& Winberg G 1999 A new picornavirus isolated from bank voles (Clethrionomys glareolus). Virology 255 86-93.

Niklasson B, Heller KE, Schonecker B, Bildsoe M, Daniels T, Hampe CS, Widlund P, Simonson WT, Schaefer JB, Rutledge E et al. 2003a Development of type 1 diabetes in wild bank voles associated with islet autoantibodies and the novel ljungan virus. International Journal of Experimental Diabesity Research 4 35-44.

Niklasson B, Hornfeldt B, Nyholm E, Niedrig M, Donoso-Mantke O, Gelderblom HR \& Lernmark A $2003 b$ Type 1 diabetes in Swedish bank voles (Clethrionomys glareolus): signs of disease in both colonized and wild cyclic populations at peak density. Annals of the New York Academy of Sciences 1005 $170-175$.

Niklasson B, Samsioe A, Blixt M, Sandler S, Sjoholm A, Lagerquist E, Lernmark A \& Klitz W 2006 Prenatal viral exposure followed by adult stress produces glucose intolerance in a mouse model. Diabetologia 49 2192-2199.

Robertson RP, Harmon J, Tran PO, Tanaka Y \& Takahashi H 2003 Glucose toxicity in beta-cells: type 2 diabetes, good radicals gone bad, and the glutathione connection. Diabetes 52 581-587.

Rossetti L, Giaccari A \& DeFronzo RA 1990 Glucose toxicity. Diabetes Care 13 610-630.

Sandler S, Bendtzen K, Borg LA, Eizirik DL, Strandell E \& Welsh N 1989 Studies on the mechanisms causing inhibition of insulin secretion in rat pancreatic islets exposed to human interleukin-1 beta indicate a perturbation in the mitochondrial function. Endocrinology 124 1492-1501.

Schoenecker B, Heller KE \& Freimanis T 2000 Development of stereotypies and polydipsia in wild caught bank voles (Clethrionomys glareolus) and their laboratory-bred offspring. Is polydipsia a symptom of diabetes mellitus? Applied Animal Behaviour Science 68 349-357. 
Svensson C, Sandler S \& Hellerstrom C 1993 Lack of long-term beta-cell glucotoxicity in vitro in pancreatic islets isolated from two mouse strains (C57BL/6J; C57BL/KsJ) with different sensitivities of the beta-cells to hyperglycaemia in vivo. Journal of Endocrinology 136 289-296.

Weir GC, Leahy JL \& Bonner-Weir S 1986 Experimental reduction of B-cell mass: implications for the pathogenesis of diabetes. Diabetes/Metabolism Reviews 2 125-161.

Weir GC, Marselli L, Marchetti P, Katsuta H, Jung MH \& Bonner-Weir S 2009 Towards better understanding of the contributions of overwork and glucotoxicity to the beta-cell inadequacy of type 2 diabetes. Diabetes, Obesity and Metabolism 11 82-90.
Wilkin TJ 2001 The accelerator hypothesis: weight gain as the missing link between type I and type II diabetes. Diabetologia 44 914-922.

Yoon JW \& Jun HS 2005 Autoimmune destruction of pancreatic beta cells. American Journal of Therapeutics 12 580-591.

Received in final form 5 May 2010

Accepted 6 May 2010

Made available online as an Accepted Preprint

7 May 2010 